Tersedia Online di http://journal2.um.ac.id/index.php/jmsp/

ISSN Online : 2541-4429

\title{
PERBEDAAN MOTIVASI BELAJAR DAN PRESTASI AKADEMIK ANTARA MAHASISWA BIDIKMISI DAN REGULER
}

\author{
Silvia Retnaningtyas \\ Bambang Budi Wiyono \\ Achmad Supriyanto

\begin{abstract}
Jurusan Administrasi Pendidikan Fakultas Ilmu Pendidikan
Universitas Negeri Malang, Jl. Semarang 5 Malang 65145
\end{abstract} \\ Email: silviaretnaningtyas@gmail.com
}

\begin{abstract}
This research aims to investigate the differences of learning motivation and academic achievement between bidikmisi and regular students at Faculty of Education State Universtiy of Malang (FIP UM). The analysis technique using quantitative method is descriptive comparative. Results showed that (1) learning motivation of both group of student is classified as moderately sufficient, (2) the academic achievement is identified as in highly distinction, (3) there is no difference of learning motivation between bidikmisi and regular students,(4) however, academic achievement differs among both groups.
\end{abstract}

Keyword: learning motivation, academic achievement, bidikmisi students

\begin{abstract}
Abstrak: Penelitian ini bertujuan untuk mengetahui ada tidaknya perbedaan motivasi belajar dan prestasi akademik antara mahasiswa bidikmisi dan reguler di Fakultas Ilmu Pendidikan Universitas Negeri Malang (FIP UM). Teknik analisis dengan metode kuantitatif yaitu deskriptif komparatif. Hasil analisis menunjukkan (1) motivasi belajar mahasiswa bidikmisi dan reguler dalam kualifikasi sedang, (2) prestasi akademik mahasiswa bidikmisi dan reguler memiliki predikat dengan pujian, (3) tidak ada perbedaan motivasi belajar antara mahasiswa bidikmisi dan reguler, (4) ada perbedaan prestasi akademik antara mahasiswa bidikmisi dan reguler.
\end{abstract}

Kata kunci: motivasi belajar, prestasi akademik, mahasiswa bidikmisi

Motivasi belajar merupakan daya penggerak yang menentukan seseorang untuk beraktivitas dan seberapa sering aktivitas tersebut dilakukan. Motivasi sebagai daya penggerak akan menimbulkan dan menjamin serta mengarahkan kegiatan belajar peserta didik hingga tujuannya dapat tercapai (Wahab, 2016:128). Motivasi menjadi sebuah alasan seseorang untuk bertindak. Dua orang dengan kemampuan yang sama dan memiliki kecenderungan berprestasi yang sama, akan memiliki hasil yang berbeda tatkala salah satu di antara keduanya memiliki motivasi yang lebih tinggi dari yang lain. Motivasi menjadi salah satu faktor penentu seseorang berhasil atau tidak dalam meraih tujuan yang telah ditetapkan. Belajar tanpa adanya motivasi akan sulit kiranya untuk berhasil secara optimal (Hamalik, 2011:108). Kenyataannya, motif seseorang untuk belajar itu berbeda- beda, ada yang belajar karena ingin menambah pengetahuan dan kemampuan, namun ada juga yang belajar karena ingin mendapatkan hadiah atau takut dihukum orangtua. Perbedaan motivasi tersebut dikarenakan jenis motivasi itu ada dua, yaitu motivasi intrinsik dan motivasi ekstrinsik (Djamarah, 2002:115). Motivasi intrinsik merupakan motivasi yang berasal dari dalam diri individu yang munculnya tidak memerlukan pengaruh orang lain. Indikator-indikator motivasi intrinsik antara lain: 1) hasrat dan keinginan berhasil; 2) dorongan kebutuhan belajar; 3) kesadaran; 4) minat terhadap bidang ilmu yang dipelajari; 5) harapan akan cita-cita; dan 6) orientasi mengikuti pendidikan tinggi. Motivasi ekstrinsik adalah motivasi yang berasal dari luar individu, berfungsinya ketika ada pengaruh dari orang lain dan lingkungan. Indikatorindikator motivasi ekstrinsik sebagai berikut: 1) 
penghargaan atau hadiah, 2) lingkungan belajar yang kondusif, dan 3) kegiatan belajar yang menarik.

Teori-teori motivasi yang relevan, yaitu teori kebutuhan Maslow dan teori kebutuhan McClelland. Menurut Maslow (dalam Saleh, 2008:190),manusia memiliki lima tingkat kebutuhan yang mendasar, yaitu: kebutuhan fisiologis, kebutuhan rasa aman dan perlindungan, kebutuhan sosial, kebutuhan akan penghargaan, dan kebutuhan akan aktualisasi diri. Kebutuhan fisiologis, terkait kebutuhan dasar, seperti pangan, sandang, papan, dan kesehatan. Kebutuhan rasa aman dan perlindungan, terkait perlindungan dari bahaya dan ancaman. Kebutuhan sosial, yaitu kebutuhan untuk dicintai, diakui dan kerjasama. Kebutuhan akan penghargaan, terkait kebutuhan dihargai karena prestasi, status dan pekerjaan. Kebutuhan akan aktualisasi diri, yaitu kebutuhan untuk mempertinggi potensi yang dimiliki. Teori kebutuhan McClelland berfokus pada tiga kebutuhan (Robbins, 2003:212-219), yaitu: kebutuhan berprestasi, berkuasa dan berafiliasi. Kebutuhan berprestasi terdiriatas: dorongan untuk melebihi, mencapai standar-standar, berusaha keras untuk berhasil. Kebutuhan berkuasa, merupakan kebutuhan untuk membuat individu lain berperilaku sedemikian rupa sehingga mereka tidak akan berperilaku sebaliknya. Kebutuhan berafiliasi adalah keinginan untuk menjalin hubungan antarpersonal yang ramah dan akrab.

Tujuan peserta didik belajar salah satunya adalah untuk meraih prestasi yang tinggi. Prestasi belajar merupakan tolok ukur keberhasilan proses belajar. Prestasi merupakan suatu hasil yang dicapai baik oleh individu maupun kelompok (Djamarah, 1994:19). Setiap mahasiswa mempunyai kebutuhan berprestasi berbedabeda tergantung pada semangatnya. Namun, pada dasarnya semua mahasiswa menginginkan prestasi yang baik. Selain itu, ada beberapa faktor yang dapat mempengaruhi mahasiswa berprestasi yaitu faktor intern dan faktor ekstern (Slameto, 2003:54-72). Faktor intern berkaitan dengan keadaan jasmaniah, psikologis, dan kesehatan, sedangkan faktor ekstern terkait akan kondisi lingkungan keluarga, sekolah dan masyarakat. Prestasi belajar mahasiswa dalam penelitian ini dilihat dari nilai prestasi akademik yang berupa Indeks Prestasi Kumulatif (IPK) yang ia dapat di setiap akhir perkuliahan.

Mahasiswa FIP UM terbagi menjadi dua kategoriyaitumahasiswabidikmisidanmahasiswa reguler. Mahasiswa bidikmisi merupakan mahasiswa yang diterima melalui jalur beasiswa khusus dengan mempertimbangkan prestasi belajar di sekolah dan diutamakan dari keluarga yang kurang mampu serta memiliki keinginan yang kuat untuk meneruskan pendidikan ke perguruan tinggi. Mahasiswa reguler adalah mahasiswa yang mendaftar dengan biaya sendiri dan tidak mendapat beasiswa bidikmisi. Mahasiswa bidikmisi memiliki berbagai macam tuntutan dalam proses penyelesaian studinya. Tuntutan tersebut di antaranya yaitu, prestasi akademik yang baik, wajib membuat program kreativitas mahasiswa (PKM), harus mengikuti salah satu kegiatan organisasi mahasiswa baik organisasi pemerintahan mahasiswa maupun organisasi non pemerintahan mahasiswa dan wajib lulus tepat waktu dengan prestasi baik. Kecenderungan mahasiswa bidikmisi memiliki motivasi tinggi dan kebutuhan berprestasi yang lebih baik dari mahasiswa reguler, menjadi hal yang menarik untuk diteliti.

Menurut hasil penelitian yang dilakukan oleh Sucahyo (2014), menunjukkan bahwa ada perbedaan hasil prestasi belajar akademik antara mahasiswa bidik misi dan non bidik misi di Prodi S1 Penjaskesrek. Hidayati (2010) yang juga melakukan penelitian terkait motivasi dan prestasi belajar mahasiswa penerima beasiswa dan non beasiswa menunjukkan hasil bahwa ada perbedaan motivasi dan prestasi belajar antara mahasiswa penerima dan bukan penerima beasiswa di AP FIP UM. Selain itu, penelitian yang dilakukan oleh Lutviasari (2015) tentang motivasi berprestasi menunjukkan bahwa ada perbedaan motivasi berprestasi antara siswa reguler dengan siswa Program Keluarga Harapan (PKH).

\section{METODE}

Penelitian ini menggunakan pendekatan kuantitatif dengan rancangan deskriptifkomparatif. Rancangan deskriptif digunakan peneliti untuk mengungkapkan motivasi belajar dan prestasi akademik mahasiswa FIP UM baik yang menerima bidikmisi maupun reguler, sedangkan rancangan komparatif digunakan untuk mengetahui ada atau tidaknya perbedaan 
motivasi belajar dan prestasi akademik antara mahasiswa bidikmisi dan reguler di FIP UM. Variabel dalam penelitian ini, yaitu: motivasi belajar dan prestasi akademik (dependen) dan mahasiswa bidikmisi dan reguler (independen). Populasi yang digunakan dalam penelitian ini adalah mahasiswa bidikmisi dan reguler di FIP UM angkatan 2013, 2014, dan 2015.Pengambilan sampel dilakukan dengan teknik proportional random sampling dan penentuan anggota sampel menggunakan teknik sampling sistematis. Jumlah seluruh sampel sebanyak 384 yang terdiri dari 64 mahasiswa bidikmisi dan 284 mahasiswa reguler.

Teknik pengumpulan data penelitian menggunakan angket atau kuesioner dan dokumentasi. Angket yang digunakan adalah jenis angket tertutup untuk mengukur motivasi belajar mahasiswa. Dokumentasi digunakan untuk mendapat data tentang jumlah mahasiswa dan nilai IPK. Teknik analisis data menggunakan teknik analisis deskriptif, uji asumsi klasik dan uji beda multivariat (MANOVA).

\section{HASIL DAN PEMBAHASAN}

\section{Hasil}

\section{Motivasi Belajar Mahasiswa Bidikmisi}

Persentase motivasi belajar mahasiswa bidikmisi FIP UM sebagaimana diuraikan dalam diagram Gambar 1.

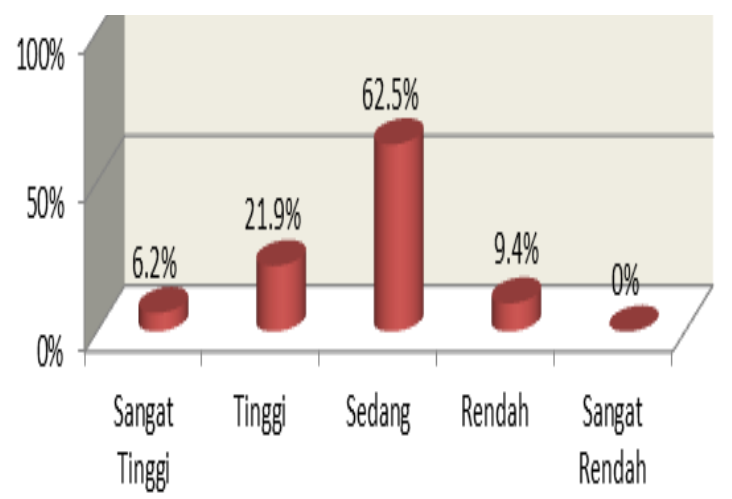

Gambar 1 Persentase Motivasi Belajar Mahasiswa

\section{BidikmisiFIP UM}

Berdasarkan Gambar 1 di atas dapat diketahui bahwa dari 64 responden, sebanyak $4(6,2 \%)$ responden memiliki kualifikasi motivasi belajar sangat tinggi, $14(21,9 \%)$ responden memiliki kualifikasi tinggi, $40(62,5 \%)$ responden memiliki kualifikasi sedang, $6(9,4 \%)$ responden memiliki kualifikasi rendah serta tidak ada $(0 \%)$ responden yang memiliki kualifikasi motivasi belajar sangat rendah.Skor rata-rata keseluruhan untuk motivasi belajar mahasiswa bidikmisiadalah 115,2913 dan termasuk dalam kualifikasi sedang.

\section{Motivasi Belajar Mahasiswa Reguler}

Persentase motivasi belajar mahasiswa reguler FIP UM sebagaimana diuraikan dalam diagram Gambar 2.

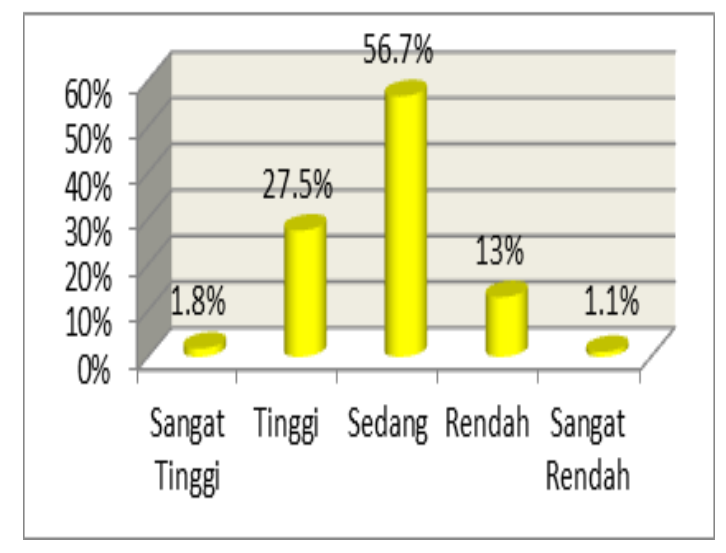

Gambar 2 Persentase Motivasi Belajar Mahasiswa Reguler FIP UM

Berdasarkan Gambar 2 di atas dapat diketahui bahwa dari 284 responden, sebanyak 5 $(1,8 \%)$ responden memiliki kualifikasi motivasi belajar sangat tinggi, $78(27,5 \%)$ responden memiliki kualifikasi tinggi, $161 \quad(56,7 \%)$ responden memiliki kualifikasi sedang, 37 (13 \%) responden memiliki kualifikasi rendah dan 3 $(1,1 \%)$ responden memiliki kualifikasi motivasi belajar sangat rendah. Skor rata-rata keseluruhan untuk motivasi belajar mahasiswa reguler adalah 114,2312dan termasuk dalam kualifikasi sedang.

\section{Prestasi Akademik Mahasiswa Bidikmisi}

Persentase prestasi akademik mahasiswa bidikmisi FIP UM dapat dilihat dalam diagram Gambar 3. 


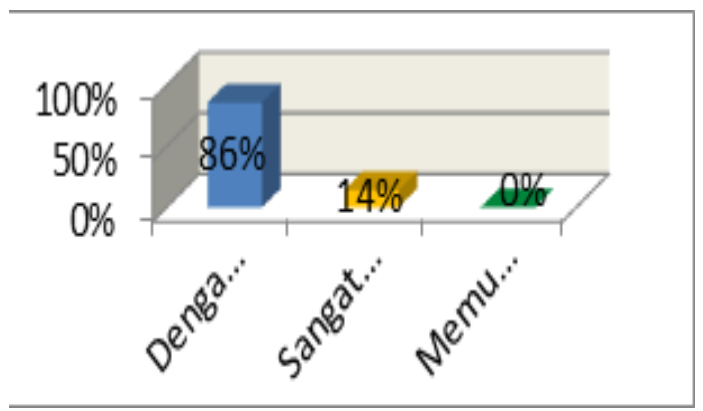

Gambar 3 Persentase Prestasi Akademik Mahasiswa Bidikmisi FIP UM

Berdasarkan Gambar 3 di atas dapat diketahui bahwa dari 64 responden, sebanyak 55 (86 \%) responden menunjukkan prestasi akademik dalam predikat dengan pujian, 9 (14 \%) responden menunjukkan prestasi akademik dengan predikat sangat memuaskan dan tidak ada $\left(\begin{array}{ll}0 & \%\end{array}\right)$ responden yang menunjukkan prestasi akademik dengan predikat memuaskan. Skor rata-rata keseluruhan prestasi akademik mahasiswa bidikmisi adalah 3,62 dan termasuk dalam predikat dengan pujian.

\section{Prestasi Akademik Mahasiswa Reguler}

Persentase prestasi akademik mahasiswa reguler FIP UM dapat dilihat dalam diagram Gambar 4.

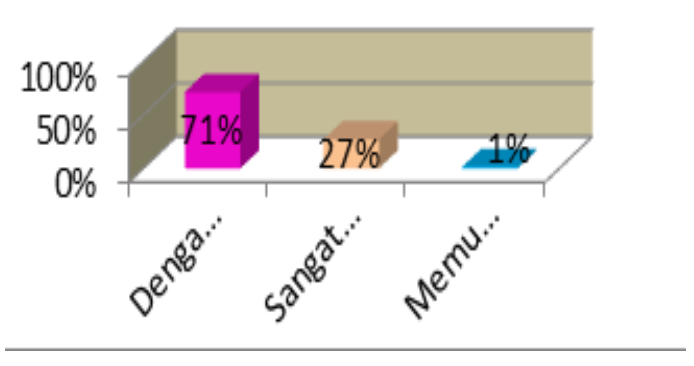

Gambar 4 Persentase Prestasi Akademik Mahasiswa Reguler FIP UM

Berdasarkan Gambar 4 di atas dapat diketahui bahwa dari 284 orang responden, sebanyak $203(71 \%)$ responden menunjukkan prestasi akademik dalam predikat dengan pujian, 77 (27 \%) responden menunjukkan prestasi akademik dengan predikat sangat memuaskan dan $4(1 \%)$ responden menunjukkan prestasi akademik dengan predikat memuaskan. Ratarata keseluruhan prestasi akademik mahasiswa reguler adalah 3,55 dan termasuk dalam predikat dengan pujian.

\section{Hasil Analisis Uji Beda}

Hasil analisis data perbedaan motivasi belajar dan prestasi akademik antara mahasiswa bidikmisi dan reguler di FIP UM menggunakan MANOVA dapat dilihat pada Tabel 1.

\section{Tabel 1 Hasil Analisis Data Perbedaan Motivasi Belajar dan Prestasi Akademik antara} Mahasiswa Bidikmisi dan Reguler di FIP UM

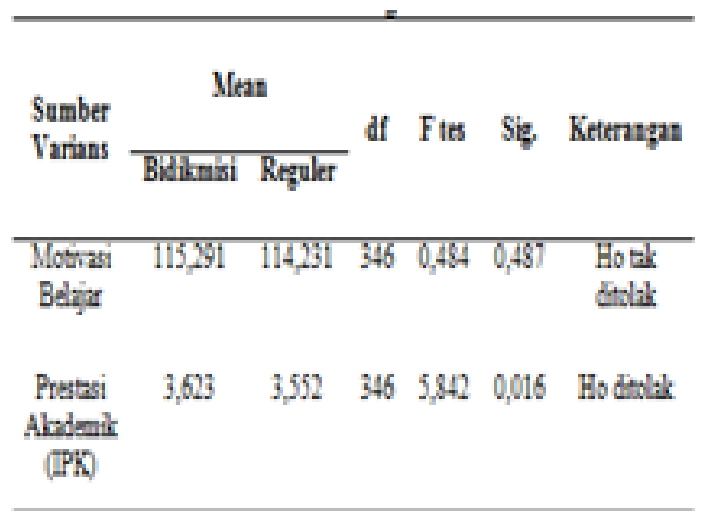

Berdasarkan hasil uji Between Subjects Effects, terlihat nilai $\mathrm{F}$ tes untuk motivasi belajar mahasiswa sebesar 0,484 dengan angka sig. 0,487 yang berarti di atas $0,05(0,487>0,05)$ maka H0 tak ditolak, yang berarti tidak ada perbedaan motivasi belajar antara mahasiswa bidikmisi dan mahasiswa reguler. Selanjutnya, nilai $\mathrm{F}$ tes untuk prestasi akademik mahasiswa sebesar 5,842 dengan angka sig. 0,016 yang berarti di bawah $0,05(0,016<0,05)$ maka H0 ditolak, hal ini berarti ada perbedaan prestasi akademik (IPK) antara mahasiswa bidikmisi dan mahasiswa reguler.

\section{PEMBAHASAN}

\section{Motivasi Belajar Mahasiswa}

Berdasarkan hasil analisis data variabel motivasi belajar pada mahasiswa bidikmisi dan reguler di FIP UM, dapat disimpulkan bahwa motivasi belajar yang dimiliki oleh kedua kategori mahasiswa yaitu bidikmisi dan reguler sama-sama berada pada kualifikasi 'sedang'. Motivasi belajar pada kedua kategori mahasiswa tersebut dapat dipengaruhi oleh beberapa hal 
yang berasal dari dalam diri individu maupun dari luar diri individu. Ada dua jenis motivasi belajar, yaitu motivasi intrinsik dan motivasi ekstrinsik (Djamarah, 2002:115). Dimyati dan Mudjiono (2009:97-99) memaparkan beberapa faktor yang menjadi penyebab seseorang termotivasi yaitu, adanya cita-cita dan aspirasi siswa untuk mewujudkan aktualisasi diri, kemampuan siswa yang mendukung, kondisi diri siswa (rohani dan jasmani) serta kondisi lingkungan siswa (alam dan sosial). Berdasarkan pendapat di atas, dapat digolongkan bahwa cita-cita dan aspirasi, kemampuan serta kondisi siswa merupakan fakor intrinsik. Sedangkan kondisi lingkungan siswa, merupakan faktor ekstrinsik. Sejalan dengan pendapat Dimyati dan Mudjiono (2009:9799), pada penelitian ini digunakan beberapa indikator motivasi intrinsik dan ekstrinsik diantaranya, untuk indikator motivasi intrinsik yaitu adanya hasrat dan keinginan berhasil, dorongan kebutuhan belajar, kesadaran, minat terhadap bidang ilmu yang dipelajari, harapan akan cita-cita dan orientasi mengikuti pendidikan tinggi. Indikator motivasi ekstrinsik, antara lain adanya pemberian penghargaan atau hadiah, lingkungan belajar yang kondusif dan adanya kegiatan belajar yang menarik. Motivasi menjadi daya pendorong bagi seseorang untuk melakukan aktivitas, khususnya aktivitas belajar.

\section{Prestasi Akademik Mahasiswa}

Berdasarkan hasil analisis data prestasi akademik pada mahasiswa bidikmisi dan reguler, dapat disimpulkan bahwa prestasi akademik mahasiswa bidikmisi dan reguler sama-sama berada dalam kategori 'dengan pujian'. Hal ini menunjukkan bahwa keduanya, baik mahasiswa bidikmisi maupun reguler berusaha dengan keras untuk mendapatkan prestasi dengan nilai yang tinggi. Ada dua macam faktor yang dapat mempengaruhi prestasi belajar peserta didik, yaitu faktor intern dan faktor ekstern (Slameto, 2003:54-72). Faktor intern adalah yang berasal dari dalam diri individu, yang terkait dengan jasmani, psikologi dan rohani. Faktor ekstern antara lain, keluarga, sekolah dan masyarakat. Faktor-faktor tersebut saling berinteraksi langsung dan mempengaruhi prestasi mahasiswa. Motif menjadi salah satu faktor intern (psikologi) yang turut mempengaruhi prestasi akademik peserta didik sehingga motivasi belajar mahasiswa turut mempengaruhi mahasiswa untuk berprestasi. Kedua jenis faktor tersebut, yaitu intern dan ekstern saling berinteraksi dan mempunyai peran masing-masing dalam mempengaruhi prestasi akademik mahasiswa. Maka, kondisi diri dan jiwa serta lingkungan mahasiswa haruslah menjadi perhatian agar ia dapat berprestasi secara maksimal.

Dari hasil analisis dan pembahasan hasil analisis data terkait motivasi belajar dan prestasi akademik mahasiswa FIP UM di atas, diketahui bahwa motivasi belajar mahasiswa dalam kualifikasi sedang namun prestasi akademik mahasiswa dalam predikat dengan pujian. Artinya, dengan motivasi belajar yang sedang mahasiswa telah mampu mencapai hasil yang maksimal.

\section{Perbedaan Motivasi Belajar antara Mahasiswa Bidikmisi dan Reguler}

Berdasarkan hasil analisis uji beda dengan MANOVA, diketahui bahwa H0 tak ditolak, dengan kata lain tidak ada perbedaan motivasi belajar antara mahasiswa bidikmisi dan mahasiswa reguler. Mahasiswa bidikmisi dan reguler tidak memiliki perbedaan motivasi belajar dikarenakan motivasi mereka baik intrinsik maupun ekstrinsik dalam tingkatan sama. Pada motivasi intrinsik, dorongan kebutuhan belajar mahasiswa bidikmisi dan reguler menjadi salah satu motif dan pendorongnya untuk semangat belajar. Hal ini sejalan dengan teori kebutuhan berprestasi menurut McClelland yaitu memiliki dorongan untuk melebihi, mencapai standarstandar, dan berusaha keras untuk berhasil dalam mencapai prestasi. Mahasiswa bidikmisi dan reguler sama-sama memiliki kebutuhan terkait prestasi pada tingkatan yang sama, sehingga motivasi belajarnya pun berada pada tingkat kebutuhan yang sama. Maslow dengan teori hierarki kebutuhannya, juga menyebutkan bahwa salah satu kebutuhan manusia adalah kebutuhan aktualisasi diri dan dalam penelitian ini menjadi salah satu motivasi yang menggerakkan mahasiswa untuk meraih tujuannya dan membuktikan kemampuannya. Mahasiswa bidikmisi dan reguler sama-sama memiliki kebutuhan akan aktualisasi diri, sehingga keduanya sama-sama berusaha keras untuk memenuhi kebutuhan tersebut. Pada motivasi 
ekstrinsik tercermin pada adanya pemberian hadiah atau penghargaan, dalam penelitian ini yaitu adanya beasiswa atau tidak. Mahasiswa bidikmisi yang merupakan penerima beasiswa dan mahasiswa reguler tidak terpengaruh oleh adanya pemberian beasiswa. Hal ini bisa jadi dikarenakan, mahasiswa penerima beasiswa (bidikmisi) sudah tidak termotivasi lagi, karena beasiswa yang ia dapatkan telah menjadi miliknya sejak ia menjadi calon mahasiswa sampai dia lulus kuliah nanti. Bagi mahasiswa reguler, barangkali tidak ada minat untuk mendapatkan beasiswa lain sehingga motivasinya tidak dapat tumbuh dan meningkat.

Hasil penelitian ini menggugurkan hasil penelitian terdahulu yang dilakukan oleh Hidayati (2010) yaitu ada perbedaan motivasi belajar antara mahasiswa penerima dan bukan penerima beasiswa di AP FIP UM dan penelitian yang dilakukan oleh Lutviasari (2015) yaitu ada perbedaan motivasi berprestasi antara siswa reguler dengan siswa penerima beasiswa Program Keluarga Harapan (PKH). Perbedaan hasil penelitian yang peneliti lakukan dengan penelitian terdahulu, dapat disebabkan oleh beberapa faktor antara lain pada waktu dilakukannya penelitian terdahulu mungkin peserta didik yang semulatidak mendapat beasiswa berusaha dengan giat agar bisa mendapatkan beasiswa, sehingga motivasi ekstrinsik berupa pemberian beasiswa, menjadi salah satu faktor kuat yang mendorongnya untuk giat belajar, sedangkan pada penelitian yang saat ini telah selesai dilakukan oleh peneliti, dapat disebabkan oleh motivasi intrinsik seperti hasrat dan keinginan berhasil, dorongan kebutuhan belajar, kesadaran, minat terhadap bidang ilmu yang dipelajari, harapan akan cita-cita, serta orientasi mengikuti pendidikan tinggi yang sama-sama kuat. Motivasi ekstrinsik yang berupa penghargaan atau beasiswa tidak lagi menjadi daya tarik yang kuat. Hal ini dikarenakan pada mahasiswa bidikmisi, beasiswa yang didapatkan telah ia terima sebelum dan sesudah dinyatakan diterima di perguruan tinggi sampai nanti ia lulus. Bagi mahasiswa reguler, mungkin pemberian penghargaan dan beasiswa bukan lagi hal yang dapat menarik minatnya. Menurutnya, beasiswa itu tidak penting karena orangtuanya dianggap telah mampu dan tidak membutuhkan beasiswa.

Perbedaan Prestasi Akademik antara Mahasiswa Bidikmisi dan Reguler
Berdasarkan hasil analisis uji beda dengan MANOVA, diketahui bahwa H0ditolak atau dengan kata lain ada perbedaan prestasi akademik (IPK) antara mahasiswa bidikmisi dan reguler. Jumlah skor rata-rata prestasi akademik mahasiswa bidikmisi lebih tinggi dibandingkan mahasiswa reguler. Perbedaan tersebut dapat disebabkan oleh beberapa faktor, baik yang berasal dari dalam diri maupun dari luar. Adanya perbedaan prestasi akademik antara mahasiswa bidikmisi dan reguler tersebut dapat disebabkan oleh keaktifan mahasiswa bidikmisi dalam mengikuti perkuliahan dan mengerjakan tugas, perbedaan tingkat intelegensi serta tuntutan mahasiswa bidikmisi harus berprestasi baik. Selain itu, ada faktor-faktor lain yang dapat mempengaruhi seseorang untuk berprestasi yaitu faktor intern dan ekstern (Slameto, 2003:54). Faktor intern yang ada pada diri siswa itu sendiri meliputi faktor jasmani (kesehatan dan cacat tubuh), psikologi (kesiapan, kematangan, motif, bakat, minat, dan intelegensi), dan kelelahan. Faktor yang ada pada luar individu (ekstern) meliputi lingkungan keluarga (relasi antar keluarga), sekolah (relasi antar teman dan relasi dengan guru), dan masyarakat (teman bergaul). Kedua faktor tersebut memberi perannya masing-masing dalam mempengaruhi seseorang untuk berprestasi. Pada faktor intern, perbedaan intelegensi, motif dan kesiapan mahasiswa bidikmisi dan reguler dapat menjadi penyebab perbedaan prestasi akademik antara keduanya. Pada faktor ekstern, perbedaan lingkungan teman bergaul dapat menjadi penyebab perbedaan prestasi akademik antara keduanya. Hal ini disebabkan, teman bergaul mahasiswa bidikmisi biasanya cenderung anak-anak yang berprestasi juga karena di Universitas Negeri Malang sendiri terdapat forum khusus untuk mahasiswa bidikmisi yang disebut Fomadiksi yang dapat menjadi salah satu penyebab prestasi akademik mahasiswa bidikmisi lebih tinggi atau berbeda dengan mahasiswa reguler.

Hasil penelitian ini didukung oleh hasil penelitian sebelumnya yang dilakukan oleh Sucahyo (2014) terhadap mahasiswa bidikmisi dan non bidikmisi prodi S1 Penjaskesrek di Universitas Negeri Surabaya yang menunjukkan bahwa ada perbedaan hasil prestasi belajar akademik anatara mahasiswa bidikmisi dan non bidikmisi. Selain itu, penelitian yang dilakukan 
oleh Hidayati (2010) juga menunjukkan bahwa ada perbedaan prestasi belajar antara mahasiswa penerima dan bukan penerima beasiswa. Peneliti meyakini bahwa prestasi akademik mahasiswa bidikmisi lebih tinggi dari mahasiswa reguler karena tuntutannya untuk berprestasi dengan terus meningkatkan atau mempertahankan prestasi akademiknya agar beasiswa bidikmisi yang didapatkannya tidak dicabut akibat prestasi akademiknya turun atau rendah.

\section{PENUTUP}

\section{Simpulan}

Berdasarkan temuan penelitian dan pembahasan hasil penelitian, maka dapat diambil kesimpulan sebagai berikut: (1) keseluruhan nilai rata-rata motivasi belajar mahasiswa bidikmisi dan reguler di FIP UM termasuk dalam kualifikasi sedang; (2) tingkat prestasi akademik mahasiswa bidikmisi dan reguler di FIP UM masuk dalam predikat dengan pujian; (3) hasil uji siginifikansi multivariat menunjukkan bahwa terdapat hubungan antara kategori mahasiswa dengan variabel motivasi belajar dan prestasi akademik. Pada hasil uji univariat variabel motivasi belajar menunjukkan bahwa tidak ada perbedaan motivasi belajar antara mahasiswa bidikmisi dan mahasiswa reguler; (4) hasil uji univariat variabel prestasi akademik menunjukkan bahwa ada perbedaan prestasi akademik antara mahasiswa bidikmisi dan reguler berdasarkan nilai IPK. Mahasiswa bidikmisi memiliki nilai rata-rata prestasi akademik keseluruhan yang lebih tinggi dibandingkan mahasiswa reguler.

\section{Saran}

Berdasarkan kesimpulan yang diuraikan di atas, maka peneliti mengajukan saran kepada beberapa pihak antara lain: (1) Rektor Universitas Negeri Malang, hendaknya dibuat kebijakan tentang pemenuhan kebutuhan-kebutuhan mahasiswa, seperti jaringan WiFi yang luas dan lancar serta pengadaan buku-buku terbaru di perpustakaan. Perlu juga dibuat kebijakan terkait seleksi penerimaan mahasiswa baru yaitu menambah jumlah kuota bagi mahasiswa bidikmisi, sehingga didapatkan input yang lebih unggul. (2) Dekan FIP UM, hendaknya membuat kebijakan terkaitmahasiswa bidikmisidan reguler. Serta lebih memperhatikan mahasiswa reguler dalam upaya peningkatan prestasi akademiknya, sehingga dapat mengimbangi dan menyamai prestasi akademik mahasiswa bidkimisi; (3) Para Ketua Jurusan di FIP UM, hendaknya berusaha untuk meningkatkan prestasi akademik mahasiswa reguler sehingga prestasi akademik mahasiswa reguler dan mahasiswa bidikmisi dapat seimbang atau sama; (4) Dosen, perlunya pemberian tugas dan latihan-latihan yang mampu menjadi motif bagi mahasiswa untuk belajar dan lebih memahami materi yang telah disampaikan. Membentuk kelompok-kelompok belajar bagi mahasiswa, hendaknya tiap kelompok diisi oleh mahasiswa bidikmisi dan reguler sehingga keduanya dapat saling berinteraksi dan memberikan motivasi serta dapat meningkatkan prestasi mahasiswa reguler; (5) Mahasiswa FIP UM, hendaknya mahasiswa meningkatkan motivasi belajar dan prestasi akademiknya. Mahasiswa perlu meningkatkan kemandiriannya dalam belajar, sehingga belajar tidak hanya ketika berada di kelas bersama dosen, namun juga di luar kelas agar prestasi akademiknya meningkat, terlebih pada mahasiswa reguler. (6) Peneliti Lain, hendaknya dapat mengembangkan variabel lainnya seperti prestasi non akademik mahasiswa, latar belakang pendidikan, jenis kelamin, dan hasil belajar mahasiswa ketika berada di sekolah menengah, jalur masuk perguruan tinggi, dan asal sekolah sehingga dapat menghasilkan data penelitian yang lebih bervariatif. Peneliti yang ingin melakukan penelitian sejenis, juga dapat menelusuri mengapa tidak ada perbedaan motivasi belajar antara mahasiswa bidikmisi dan reguler berdasarkan hasil yang diperoleh dari penelitian ini.

\section{DAFTAR RUJUKAN}

Dimyati \&Mudjiono. 2009. Belajar dan Pembelajaran. Jakarta: Rineka Cipta

Djamarah, S.B. 1994. Prestasi Belajar dan Kompetensi Guru.Surabaya: Usaha Nasional.

Djamarah, S.B 2002. Psikologi Belajar. Jakarta; PT Asdi Mahasatya.

Hamalik, O. 2011. Proses Belajar Mengajar. Jakarta: Bumi Aksara.

Hidayati, R.N. 2010. Perbedaan Motivasi dan Prestasi Belajar antara Mahasiswa Penerima dan Bukan Penerima Beasiswa di Jurusan Administrasi Pendidikan Fakultas Ilmu Pendidikan Universitas Negeri Malang. Skripsi Tidak Diterbitkan. 
Malang: Fakultas Ilmu Pendidikan Universitas Negeri Malang.

Lutviasari, D. 2015. Perbedaan Motivasi Berprestasi antara Siswa Reguler dengan Siswa Program Keluarga Harapan (PKH) di SD Negeri Kecamatan Boja Tahun Ajaran 2015/2016, (Online) (lib.unnes.ac.id/24108/1/1301410089. pdf) diakses pada 02 Mei 2017.

Robbins, S. 2003. Perilaku Organisasi. Jakarta: PT Indeks Kelompok Gramedia.

Saleh, A.R. 2008. Psikologi: Suatu Pengantar dalam Perspektif Islam. Jakarta: PT Raja Grafindo Persada.
Slameto. 2003. Belajar dan Faktor-faktor yang Mempengaruhinya. Jakarta: Rineka Cipta.

Sucahyo, A.Y. 2014. Perbandingan Prestasi Belajar Akademik Antara Mahasiswa Bidik Misi dan Mahasiswa Non Bidik Misi (Studi Pada Mahasiswa Prodi S1 Penjaskesrek Angkatan 2011 dan 2012 FIK), (Online), (https://ejournal. unesa.ac.id/../article.pdf) diakses pada 17 Januari 2017.

Wahab, R. 2016. Psikologi Belajar. Jakarta: PT RajaGrafindo Persada. 